\title{
Potassium Adsorption Phenomenon in Calcareous Soils of Shahrazur Plain
}

\author{
Kamil Sabir Saeed \\ Protected Agriculture Department \\ Bakrajo Technical Institute \\ Sulaimani Polytechnic University \\ Sulaimani, Iraq \\ kamil.saeed@spu.edu.iq
}

\section{Article Info \\ Volume 6 - Issue 1- June 2021}

DOI:

10.24017/science.2021.1.10

\section{Article history:}

Received 5/6/2021

Accepted 1/7/2021

\section{Keywords:}

Potassium adsorption, Freundlich model, Langmuir model, Temkin model.

\begin{abstract}
A laboratory study for adsorption of potassium (K) determination was conducted on six soils located in Sharazur plain from the Kurdistan Region of Iraq in 2021 using the batch technique method. Potassium (K) adsorption isotherms were achieved by equilibrating $5.0 \mathrm{~g}$ of soil samples with eight grades of $\mathrm{K}(0$ to $300 \mathrm{mg} \mathrm{L}^{-1}$ ) as $\mathrm{KCl}$ in $50 \mathrm{ml}$ of $0.01 \mathrm{M} \mathrm{CaCl}$ solution. To match the data of adsorption, Freundlich, Langmuir, and Temkin adsorption isotherms were used. The results show that the amount of adsorbed K ranged between (45.78 to 52.49) $\%$ added $\mathrm{K}$. The Freundlich model fit the equilibrium $\mathrm{K}$ adsorption data better for the Serwan location of soil (silty loam), as demonstrated by a greater coefficient of determination $\left(R^{2}=0.90\right)$. The value of heterogeneity factor $1 / n$ for the Freundlich model ranged from (0.34 to 0.47$) \mathrm{kg} \mathrm{mg}^{-1}$, which was less than one. The sorption processes for all of the studied soils were normal adsorption. The constant of the Langmuir isotherm $\left(K_{L}\right)$ aligned from $(0.107$ to 0.425$) \mathrm{L} \mathrm{mg}^{-1}$. Smaller $K_{L}$ values mean that more adsorbed $K$ would be transformed to a non-exchangeable form, either through the creation of crystalline $K$ or through ion occultation. The $R_{L}$ values indicate the type of isotherm, the values of $R_{L}>1$ that means the adsorption nature to be unfavorable. The Temkin equilibrium binding constant $\left(A_{T}\right)$ was high for all studied soils except the soils of Bestan Sur and Grdigo locations, the high value of $A_{T}$ indicates high binding energy. The Temkin constant $\left(b_{T}\right)$ ranged from (10.46 to 13.47) $\mathrm{J} \mathrm{mole}^{-1}$ that was related to the nature of the adsorption energy, a positive value indicates that the adsorption process is exothermic.
\end{abstract}

Copyright $\odot$ (2021Kurdistan Journal of Applied Research. All rights reserved.

\section{INTRODUCTION}

One of the fundamental nutrients for the growth of the plant is potassium $(\mathrm{K})$, and when it exists at an insufficient level in soils, plant growth is seriously hampered. Potassium is available to plants in the form of inorganic cations $\left(\mathrm{K}^{+}\right)$[1]. Over sixty (60) enzymes involved in carbohydrate production, sugar translocation, numerous enzyme actions, yield, efficiency parameters, disease tolerance, processes to resolve abiotic tension, cell permeability, and 
stomata opening are stimulated by potassium. It also affects the microbial population in the rhizosphere [2]. Various soil processes, such as the physical, chemical, and biological properties, influence $\mathrm{K}$ availability [3]. The release of potassium influences by the interaction of soil mineralogy, soil texture, and biological processes [4].

Potassium is present in the soil in four different types. Soil minerals like feldspar and mica make up (90 to 98) percent of the total potassium in the soil. Plants can only use a small portion of this potassium supply. The second type of soil potassium is non-exchangeable potassium, it is related to the $2: 1$ clay mineral and ranges from $1 \%$ to $10 \%$ of total soil $\mathrm{K}$. In the soil, the nonexchangeable potassium source functions as a potassium reserve. Non-exchangeable $\mathrm{K}$ release has a major impact on soil $\mathrm{K}$ fertility. The exchangeable or readily available potassium, which makes up 1 to 2 percent of the soil potassium, is found in the soil solution or on cation exchangeable sites [5]. The root system of the plant readily absorbs potassium from the soil solution, which is then replaced by potassium from the exchangeable sites. Since crops respond to applied potassium earlier, the rate of $\mathrm{K}^{+}$adsorption after fertilizer addition differs among soils, and thus its unpredictability is since different soils have varying potassium adsorption properties. Clay colloids can adsorb up to $57 \%$ of the applied potassium, depending on the amount and form of clay minerals [6]. Kinetic and thermodynamic variables influence the amount of potassium adsorbed on clay particles [7].

According to Jalali [8], calcareous soils with enough exchangeable $\mathrm{K}$ and $\mathrm{K}$-bearing minerals are capable of releasing enough $\mathrm{K}$ for optimal plant production. However, the exchangeable $\mathrm{K}$ in calcareous soils is not always reliable as a source of potassium for plants. The phenomenon of $\mathrm{K}$ adsorption in soils has altered the soil-plant system fertilization efficacy by converting available K into an unavailable form for plants. Due to the availability of different compelling potassium pools in the soil which could be mobilized by the chemical resistance of the mineral in the soil, understanding the process of $\mathrm{K}$ adsorption in the soil is essential [9]. A simple approach for determination $\mathrm{K}$ adsorption may aid in understanding the relationship among the adsorption of the alternative $\mathrm{K}$ soil characteristics [10]. The balance between $\mathrm{K}$ in the interlayer, the exterior, and $\mathrm{K}$ in the edge sites of the mineral crystal lattice is maintained by the solubilized $\mathrm{K}$ in soil solution which controls the potassium adsorption mechanism. The key elements impacting the equilibrium include clay mineral forms, soil $(\mathrm{pH})$, soil organic matter ( $\mathrm{SOM}, \mathrm{Al}$ $(\mathrm{OH})_{3}$, moisture state of soil, cation exchange capacity (CEC), fertilizer rate, and the process of tillage [11]. Due to the complexity of the adsorption of potassium by the soil, it is difficult to explain it by the occurrence of a single reaction. Many equations have been advanced for the calculation of soil potassium. The Freundlich, Langmuir, and Temkin adsorption isotherms are often utilized to illustrate the relationship between the potassium quantity fixed per weight unit in the soil and the potassium concentration in the solution. The Freundlich equation was initially used by Russell and Prescott in 1961, and it is the earliest adsorption equation in the soil literature. It's a mathematical statement for an adsorption model that the sympathy term declined rapidly with increasing adsorption. The Freundlich equation effectively predicted $\mathrm{K}$ adsorption for a limited range of conditions [12]. The energy of adsorption decreases as the sum of adsorption increases, according to the Freundlich equation. The Temkin isotherm includes a component that accounts for adsorbent-adsorbate interactions and it is based solely on the exterior analysis [13]. The Temkin isotherm is intensely used for an exterior energy system that is heterogeneous [14].

\section{2-METHODS AND MATERIALS}

\subsection{Study area and soil sampling}

A study was conducted on the soil of Sharazur plain, which was located between the provinces of Suleimania and Halabja, situated in the southeastern part of Kurdistan Region, Iraq (Figure 1). The soil samples were randomly taken at 0 to $30 \mathrm{~cm}$ depths of the six major agricultural locations of the plain of Shahrazur during the spring season of 2021. For soil analysis and sorption experiments, the soil samples were air- 
dried then it was grounded and screened through a (2) $\mathrm{mm}$ screen. According to Gee and Bauder [15], the pipette method was applied to obtaining the soil Particle Size Distribution (PSD) of the soil samples. A pH meter Professional Benchtop, model (BP3001), and EC meter HERMAN PAULSEN, model (D-2000 HAMBURG) was used for measuring the soil reaction $(\mathrm{pH})$ and electrical conductivity (ECe) for the soil suspension 1:2 respectively. The soil samples Cation Exchange Capacity (CEC) was determined by saturating the soil with $1 \mathrm{M}$ ammonium acetate $\left(\mathrm{NH}_{4} \mathrm{OAc}\right)$ at $\mathrm{pH}$ 8.1 as an extraction solution according to the method described by Suarez [16]. The content of Organic Matter (O.M.) was determined using Nelson and Sommer [17] technique. A quick titration method, based on the approach technique of Rayment and Higginson [18] approach, was used to quantify the total carbonate minerals in soil expressed as carbonate minerals equivalent. The Active Equivalent Carbonates (AEC), were estimated by the $0.5 \mathrm{M}$ NH4-oxalate method as described by Drouimeau [19].

\subsection{Potassium adsorption experiment procedure}

For the construction of the potassium adsorption isotherm, each soil sample of $5.0 \mathrm{~g}$ was placed into a plastic bottle of $100-\mathrm{ml}$ and then equilibrated with so $\mathrm{ml}$ of $0.01 \mathrm{M}$ $\mathrm{CaCl}_{2}$ with (soil/solution ratio of $5 / 50$ ), using various concentration of potassium (K) which were $\left(0,25,50,100,150,200,250\right.$, and $300 \mathrm{mg} \mathrm{L}^{-1} \mathrm{~K}$ as $\left.\mathrm{KCl}\right)$. The suspensions were then shaken for 2 hours at $180 \mathrm{rpm}$ and $298 \mathrm{~K}$ in a horizontal flask shaker before being allowed to equilibrate overnight. Every solution was centrifuged at $250 \mathrm{rpm}$ for 5 minutes after that, it was filtered through Whitman filter paper No. 42 and tested for K concentration using a Flame Photometer JENWAY model PFP7.

By subtracting the quantity measured in the solution which was supernatant from the original amount of added $\mathrm{K}$, the amount of $\mathrm{K}$ adsorbed was estimated, as shown below:

$$
\text { adsorbed } K=C_{o}-C_{e} \ldots \ldots \ldots(1)
$$

Where $C_{o}=$ the initial concentration of added $\mathrm{K}\left(\mathrm{mg} \mathrm{L}^{-1}\right)$ and $C_{e}=$ concentration of $\mathrm{K}\left(\mathrm{mg} \mathrm{L}^{-1}\right)$ in the equilibrium supernatant solution.

The removal efficiency was determined by computing the percentage adsorption using the formulae in Mandal et al. [20].

$$
K \text { adsorbed }(\%)=\frac{\left(\text { con.of adsorbed } K\left(m g L^{-1}\right) \times 100\right)}{C_{o}\left(m g L^{-1}\right)} \ldots
$$

According to Vanderborght and Van Grieken [21], the amount of adsorbed Kat equilibrium (mg $\mathrm{kg}^{-1}$ ) was determined as follows:

$q_{e}=\frac{\left(C_{o}-C_{e}\right) V}{W}$

Where qe represents the quantity of $\mathrm{K}$ adsorbed from the solution $\left(\mathrm{mg} \mathrm{kg}^{-1}\right)$, 


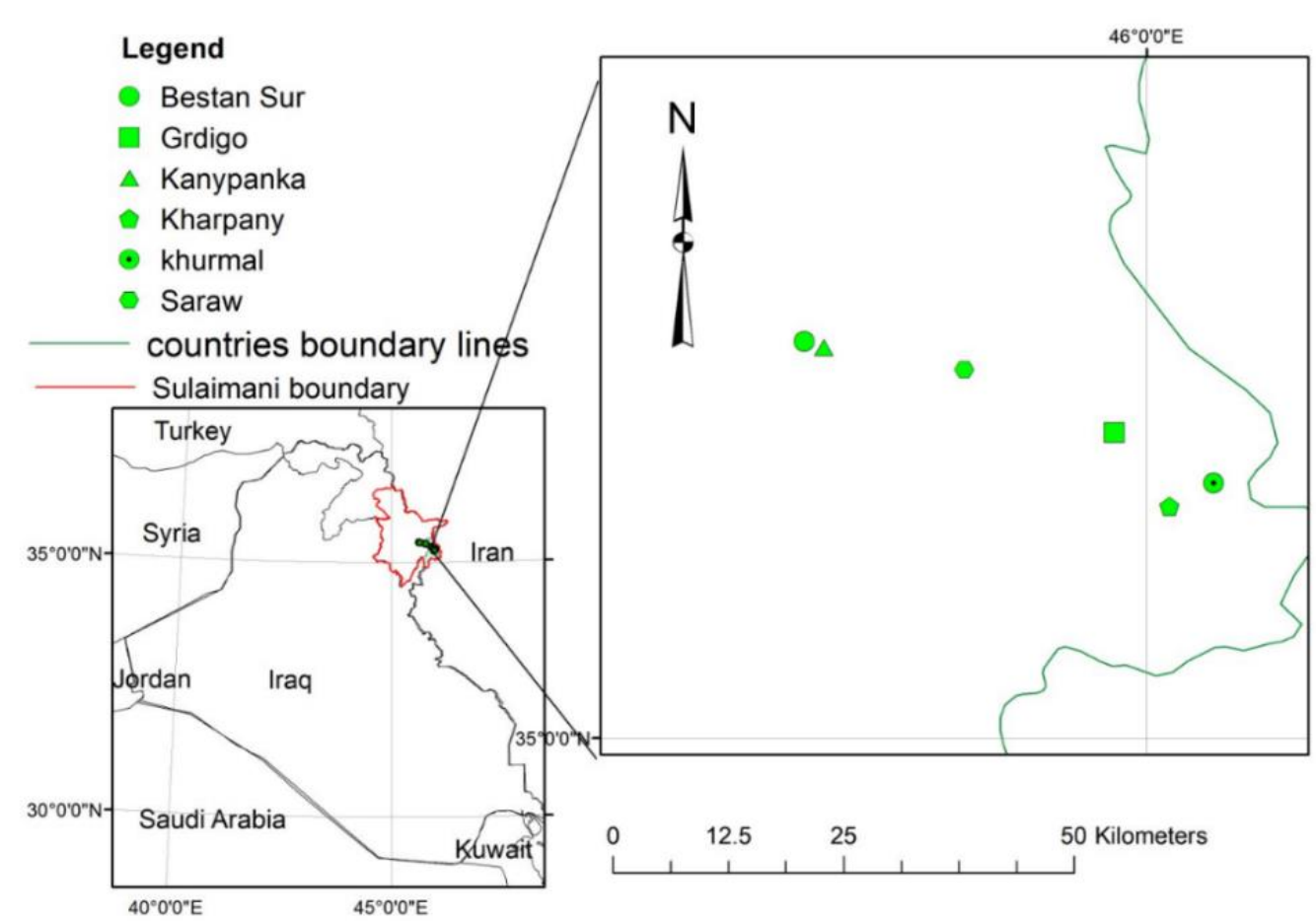

Figure 1: Geographical location of studied sites.

$V$ represents the volume of the solution (L), and $W$ represents the weight of the soil sample used in the experiment $(\mathrm{kg})$. The linearized forms of the Freundlich, Langmuir, and Temkin isotherms were used to calculate the results.

\subsection{Freundlich adsorption isotherm}

Freundlich isotherm was one of the first to propose an adsorption isotherm equation [22]. The Freundlich isotherm is an empirical model for non-ideal adsorption on homogeneous surfaces, as well as multilayer adsorption with an uneven distribution of heat of adsorption and sympathies all over the surface that was heterogeneous [23]. Based on sorption onto a heterogeneous surface, the empirical Freundlich equation is:

$\mathrm{q}_{\mathrm{e}}=\mathrm{K}_{\mathrm{F}} \mathrm{C}_{\mathrm{e}}^{(1 / \mathrm{n})}$

By taking logarithms, Eq.(4) can be rearranged to obtain a linear form. Equation (5):

$\log q_{e}=\log K_{f}+\frac{1}{n} \log C_{e}$

Where $K_{f}$ is the energy of sorption or distribution coefficient $\left(\mathrm{mg} \mathrm{kg}^{-1}\right)$. In the adsorption process, $n$ is the dimensionless constant, and $1 / n$ is a function of the strength of adsorption in the adsorption process [24]. The partition between the two phases is concentration-independent if the Freundlich affinity value $n$ equals 1 . If $1 / n$ is smaller than 1 , the value shows normal adsorption. However, if the value is more than 1, it suggests cooperative adsorption [25]. The Freundlich sympathy value, $n$ is important for consideration sorption processes and heterogeneity of the system. The process of sorption is favorable when the value of $n$ is between 1 and $10,[26,27]$. A $1 / n$ value approaching unity denotes a more homogenous system, while a $1 / n$ value near zero denotes a more heterogeneous system [28]. 


\subsection{Langmuir adsorption isotherm}

The Langmuir model assumes monolayer adsorption of solutes on homogenous sorption sites, and the Langmuir equation defines the distribution of $\mathrm{K}$ between the solid-liquid interface equilibrium.

The Langmuir isotherm was the most extensively used linear expression for studying the interactions between solute concentrations in the liquid and solid phases at equilibrium conditions [29, 30]. Equation (6) describes the Langmuir isotherm model.

$\frac{1}{q_{e}}=\frac{1}{b}+\frac{1}{b K_{L} C_{e}}$

Where qe represents the amount of adsorbed potassium per unit of soil weight $\left(\mathrm{mg} \mathrm{kg}^{-1}\right), C_{e}$ represents the concentration potassium in the solution at equilibrium $\left(\mathrm{mg} \mathrm{L}^{-1}\right)$ point, $K_{L}$ represents the bonding energy or affinity constant of potassium to the soil $\left(\mathrm{L} \mathrm{mg}^{-1}\right)$, and $b$ represents the soil's highest monolayer coverage ability while $\mathrm{K}$ is adsorbed $\left(\mathrm{mg} \mathrm{kg}^{-1}\right)$. A consecutive line with a slope of $1 / b K_{L}$ and an intercept of $1 / b$ when plotted against $1 / C_{e} . R_{L}$ is the dimensionless constant called the equilibrium parameter for Langmuir isotherm [31].

$R_{L}=\frac{1}{\left(1+K_{L} C_{o}\right)}$

where $K_{L}$ is a constant relative to bonding energy $\left(\mathrm{L} \mathrm{mg}^{-1}\right)$ and $C_{o}$ is the initial $\mathrm{K}$ concentration (mg L $\left.{ }^{-1}\right), R_{L}$ values indicate the shape of isotherm [32]. The $R_{L}$ value indicates whether the adsorption is favorable $\left(0<R_{L}<1\right)$, unfavorable $\left(R_{L}>1\right)$, linear $\left(R_{L}=1\right)$, or irreversible $\left(R_{L}=0\right)$.

According to Reyhanitabar et al. [33], the buffering capacity (MBC) which was at its highest value was estimated as the product of $K_{L}$ and $b$.

$M B C=K_{L} * b$

\subsection{The Temkin isotherm}

The Temkin isotherm was estimated that the heat of adsorption decreases in a linear rather than logarithmic manner. Furthermore, it is restricted to chemical adsorption and has homogeneous binding energy [34].

Equation (9) can be used to describe the Temkin isotherm.

$q_{e}=\frac{R T}{b_{T}} \ln \left(A_{T} C_{e}\right)$

$q_{e}=\frac{R T}{b_{T}} \ln A_{T}+\frac{R T}{b_{T}} \ln C_{e}$

The linear form of the Temkin isotherm model is given by the following [35]:

$q_{e}=B \ln A_{T}+B \ln C_{e}$

where $q e=$ the mass of $\mathrm{K}$ adsorbed per unit mass of the soil $\left(\mathrm{mg} \mathrm{kg}^{-1}\right), C_{e}$ is equilibrium solution $\mathrm{K}$ concentration $\left(\mathrm{mg} \mathrm{L}^{-1}\right), A_{T}$ is the Temkin isotherm equilibrium binding constant $\left(\mathrm{L} \mathrm{kg}^{-1}\right)$, and $B$ is a constant linked to the heat of sorption $\left(\mathrm{J} \mathrm{mol}^{-1}\right)$ computed as:

$B=\frac{R T}{b_{T}}$

where $b_{T}$ is the Temkin constant linked to the nature of the adsorption energy $\left(\mathrm{J} \mathrm{mol}^{-1}\right)$ a positive value of $b_{T}$ indicates that the adsorption process is exothermic while a negative value of $b_{T}$ is an 
indication of the endothermic process [36] $R$ is the universal gas constant $\left(8.314 \mathrm{~J} \mathrm{~mol}^{-1} \mathrm{~K}^{-1}\right), T$ stands for the temperature with an absolute value of 298 kelvin. A plot of qe versus $\ln C e$ (equation 10) results in a straight line of slope $R T / b_{T}$ and intercept $\frac{R T}{b_{T}} \ln A_{T}$

enables the determination of the isotherm constants $A_{T}$ and $b_{T}$.

\section{3-RESULTS AND DISCUSSION}

Table 1 demonstrates some of the soil characteristics (physical and chemical) that were studied previously. The concentration of equilibrium $\mathrm{K}$ in the soil solution ranged from 1.65 to $3.76 \mathrm{mg}$ $\mathrm{L}-1$ for $25 \mathrm{mg} \mathrm{L}^{-1}$ added $\mathrm{K}$, and from 170.15 to $181.81 \mathrm{mg} \mathrm{L}^{-1}$ for $300 \mathrm{mg} \mathrm{L}^{-1}$ added $\mathrm{K}$. The direct proportionality that existed was demonstrated by the linear relationship between additional $\mathrm{K}$ and equilibrium $\mathrm{K}\left(\mathrm{mg} \mathrm{L}^{-1}\right)$ (Figure 2). With increasing $\mathrm{K}$ concentrations, the percent of $\mathrm{K}$ adsorbed did not increase equally (Figure 3). The range (\%) of the adsorbed potassium $(\mathrm{K})$ was lined in a range between 84.953 to $93.421 \%$ for the added $\mathrm{K}$ concentration which was lowest $\left(25 \mathrm{mg} \mathrm{L}^{-1}\right)$ and from 39.398 to $43.284 \%$ for the maximum added concentration of $\mathrm{K}\left(300 \mathrm{mg} \mathrm{L}^{-1}\right)$. All the studied soils indicated a decrease in percentage adsorption $\mathrm{K}$ after initially adding with different $\mathrm{K}$ levels for the three first $\mathrm{K}$ levels and the presence of adsorbed $\mathrm{K}$ for all studied soils at the latest three added $\mathrm{K}$ concentration levels, are close to each other and in parallel. These results are similar to the finding by Auge et al [37]. 


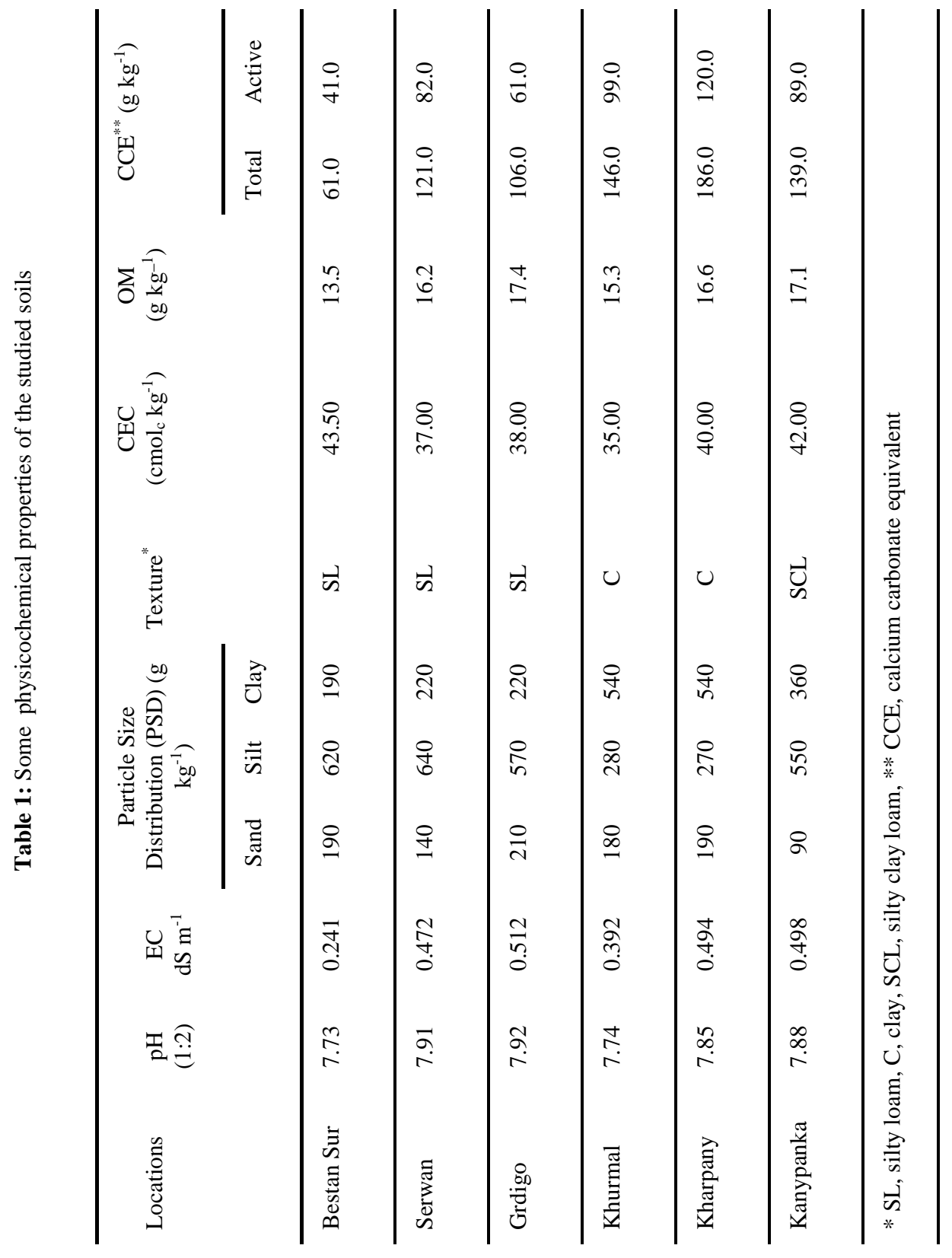



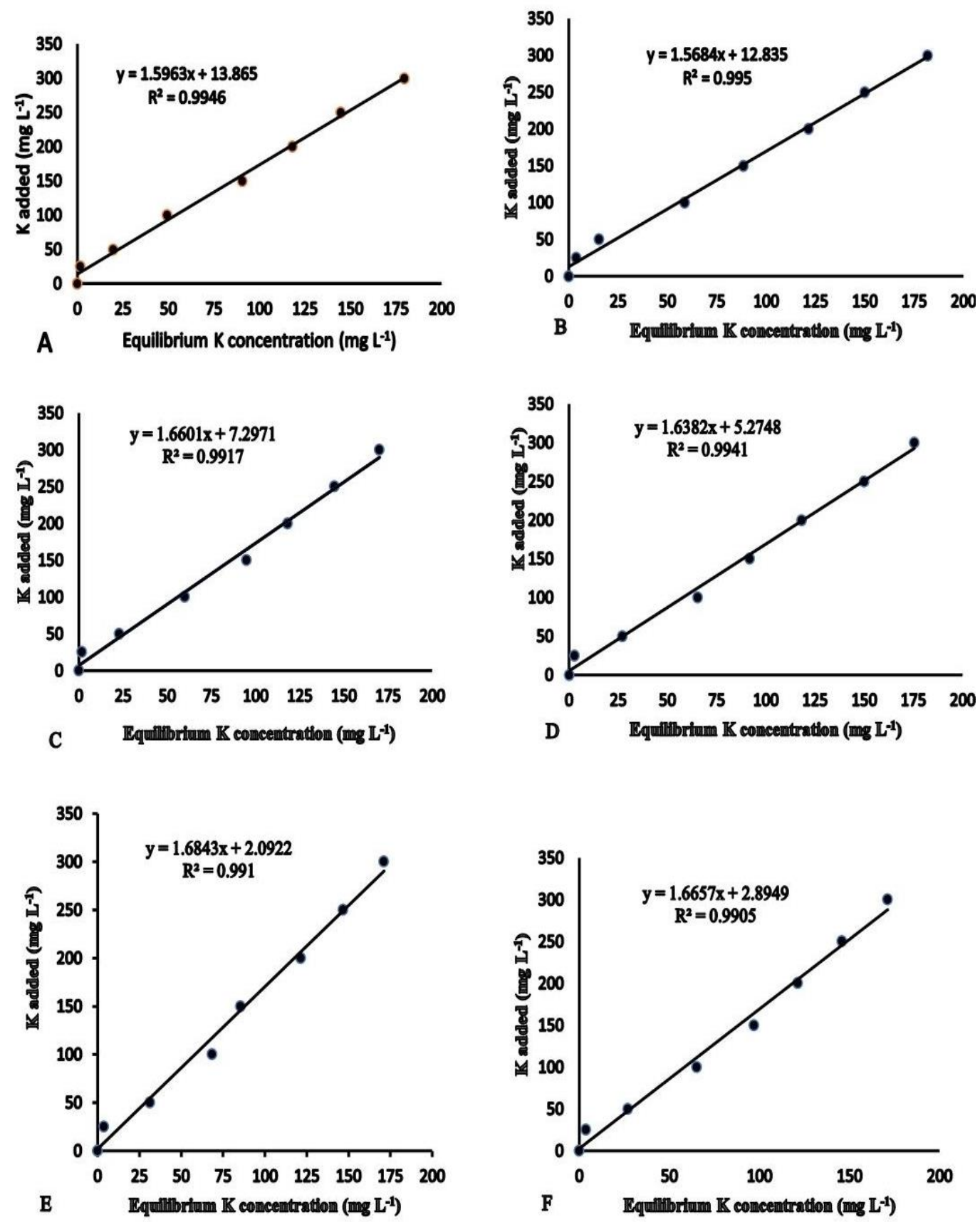

Figure 2: Potassium adsorption characteristics of (A) Bestan Sur, (B) Serwan, (C) Grdigo, (D) Khurmal. (E) Kharpany, and (F) Kanypanka locations. 


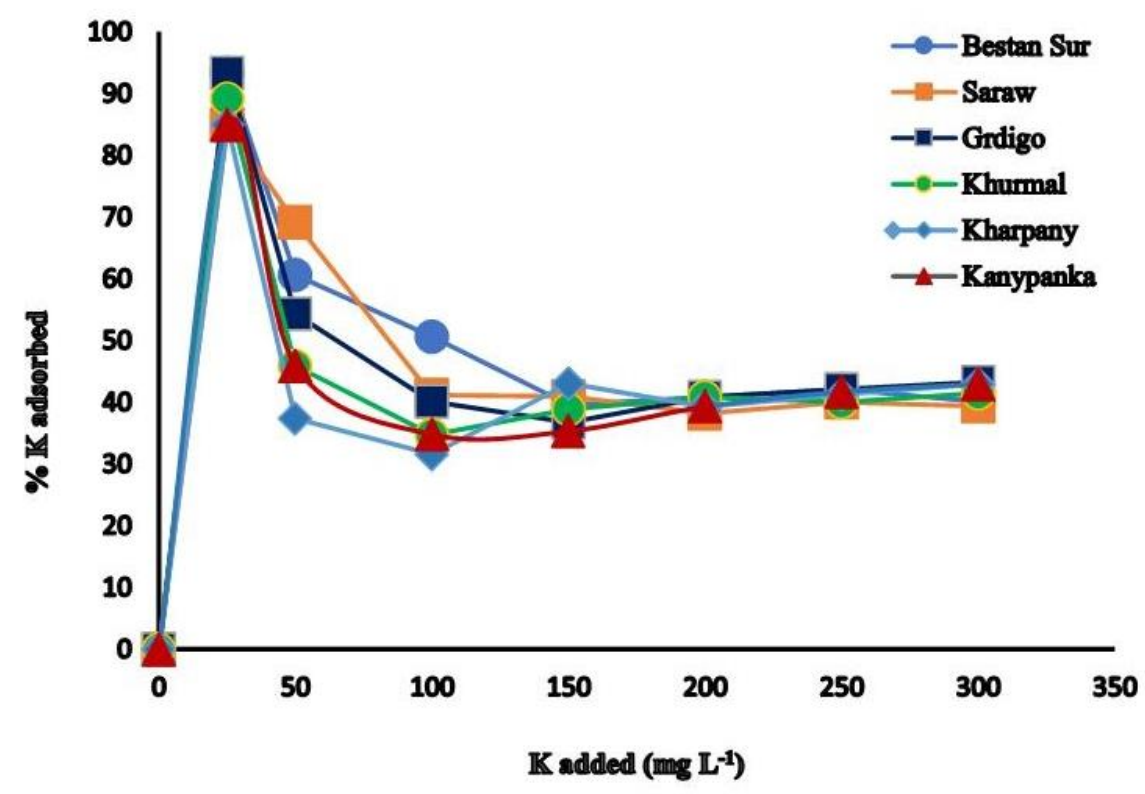

Figure 3: Percent $K$ adsorbed as a function of different $K$ concentration levels of studied soils.

\subsection{Comparison of different adsorption isotherms}

The sorption isotherms precision alters depending on the soil. In comparison to the Langmuir and Temkin models, the Freundlich model exhibited an advanced match (Figure 4) of equilibrium $\mathrm{K}$ adsorption for the soil of silty loam type at Srwan site, as demonstrated by the $\left(\mathrm{R}^{2}\right)$ values coefficient (Table 2). These findings are consistent with Kassa et al. [38], who indicated that the Freundlich model performed better than the other model in describing $\mathrm{K}$ adsorption. This was due to qualitative changes in the mineralogy and chemistry of the fractions that were separated [39].

Freundlich's isotherm assumes low adsorption energy, for the constant $K_{f}$, and $1 / n$ (Table 2) as a measure of adsorption extent [24]. The buffering capacity of the soil is performed by the constant value of $1 / n$. [40]. The $1 / n$ value is a heterogeneity parameter, and it is a function of the strength of adsorption in the adsorption process, with less $1 / n$ values indicating more heterogeneity [26]. As a result, the soils of the whole studied locations have a high heterogeneity, and a normal adsorption process [25] the $n$ parameter values reflect even if the process of sorption is favorable or not [37]. For favorable sorption processes, the value of $n$ is lies between one and ten [37,27]. Depending on the values of $n$ parameters in this study the sorption processes for the whole studied soils are favorable (Table 2). These findings are consistent with Mam Rasul [41] findings. The adsorption capacity $\left(K_{F}\right)$ Freundlich constants describe the amount of potassium $(\mathrm{K})$ held on non-specific sites they are ready to be released for uptake by plants during cropping season [24, 40]. It was 74.75 to $156.39 \mathrm{mg} \mathrm{kg}^{-1}$ on average, with a mean value $\left(112.41 \mathrm{mg} \mathrm{kg}^{-1}\right)$. The Langmuir isotherm assumes that all adsorption sites have the same affinity for the adsorbate molecules. As a result, the existence of adsorbed molecules at a nearby location is noteworthy [26]. From the intercept and slope of the straight equations of figure 5, depending on the Langmuir isotherm model's the maximum monolayer coverage capacity (b) ranged from 500.00 to $714.29 \mathrm{mg} \mathrm{kg}^{-1}$ (Table 2), all the studied soils indicated high monolayer coverage capacity possessing the best fit to Langmuir model. These findings are consistent with those of Auge et al. [37]. 

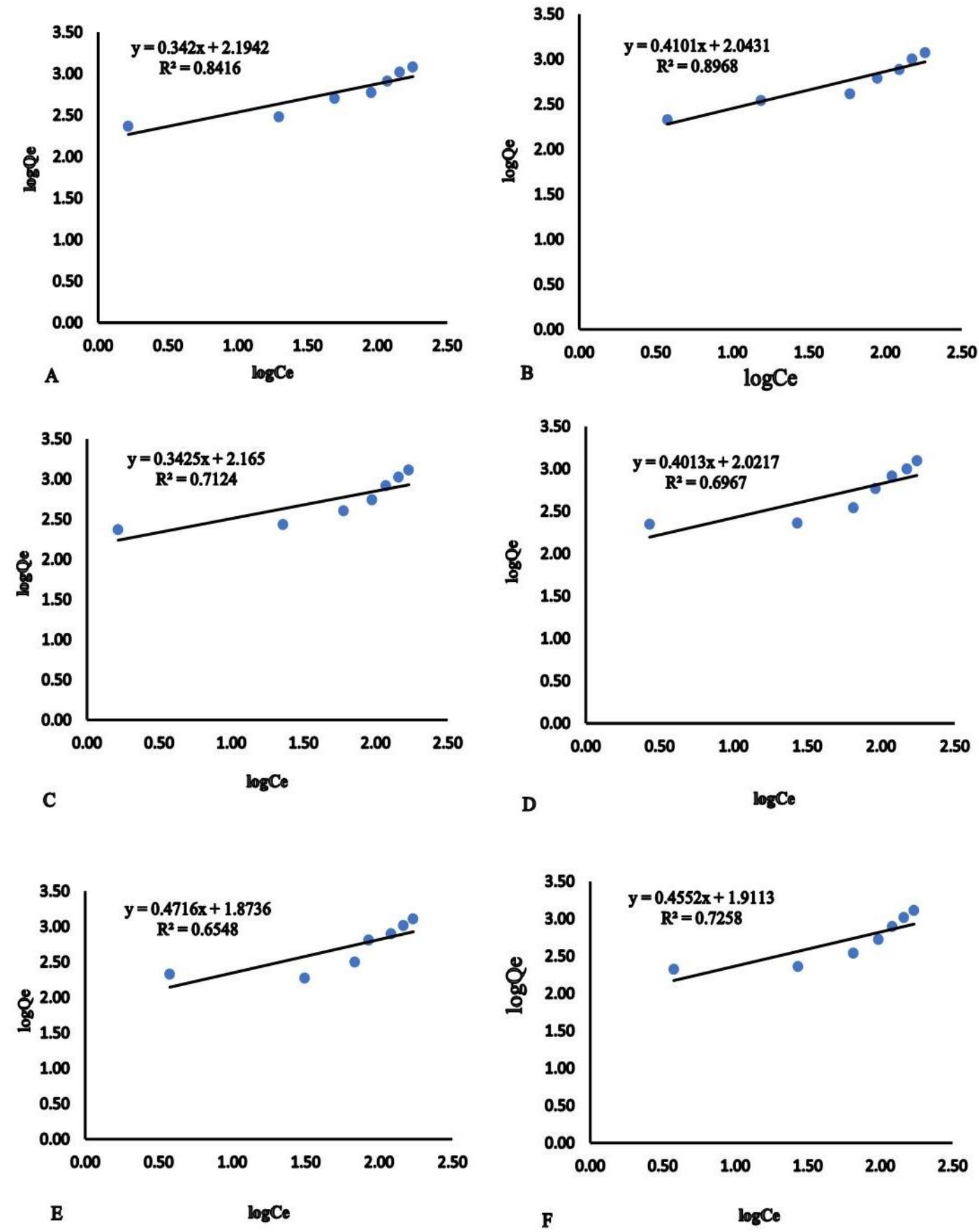

Figure 4: Freundlich adsorption isotherm for (A) Bestan Sur, (B) Serwan, (C) Grdigo, (D) Khurmal. (E) Kharpany, and (F) Kanypanka locations 


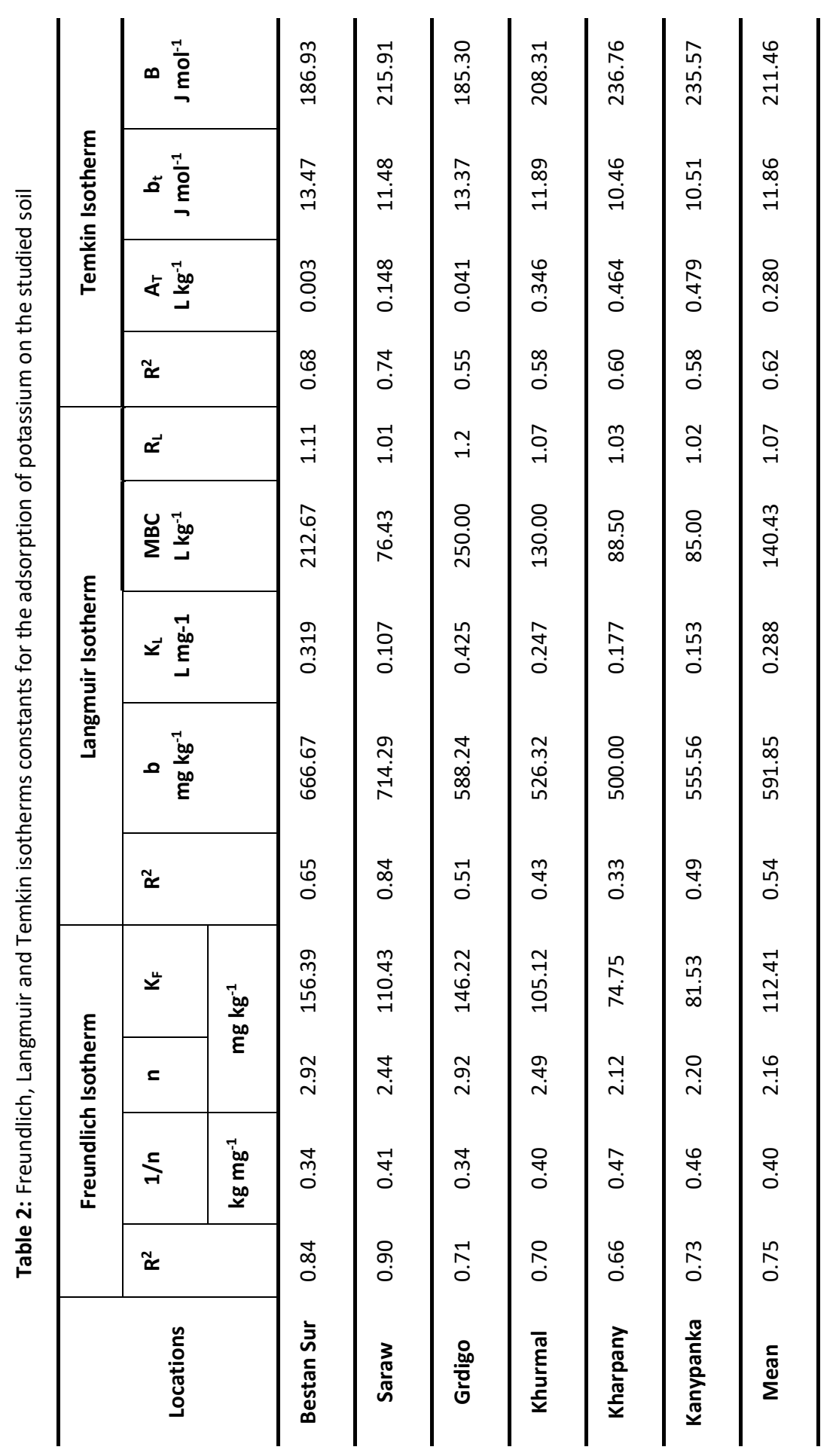

The maximum monolayer capacity (b) can be used to calculate how much fertilizer should be applied to unfertilized soil [25]. The Langmuir isotherm constant $\left(K_{L}\right)$ ranged from 0.107 to $0.425 \mathrm{Lmg}^{-1}$. Smaller $K_{L}$ values, according to Mehandi and Taylor [42], mean that the adsorbed $\mathrm{K}$ is more accessible to transform to non - exchangeable form, either through the production of crystalline $\mathrm{K}$ or through occultation through $\mathrm{K}$ ions. $K_{L}$ indicates the measurement of adsorbent 
sympathy, according to Del-Bubba et al. [43], A high $K_{L}$ value, according to Anderson and Wu [44] indicates the power of attaching to the minerals of the soil was clay. The adsorption nature of the potassium $(\mathrm{K})$ for all studied soils is unfavorable because of the diffusion coefficient values $\left(R_{L}>1\right)$ (Table 2). These results not matching with the results of Mam Rasul [41], who found that the adsorption nature of potassium for calcareous soil in the Kurdistan Region of Iraq is linear because in his study the value of $R_{L}=1$. The maximum buffering capacity (MBC) of the studied soil ranged between (85.00 to 250) $\mathrm{L} \mathrm{kg}^{-1}$ (Table 2). MBC is a capacity factor that assesses the soil's ability to release the restored $\mathrm{K}$ ions from adsorbed $\mathrm{K}$ to soil solution as mentioned by Rehman et al. [45]. The ability of a soil to give $\mathrm{K}$ to the soil solution, according to Fried and Shapiro [46], is an important component in determining a soil's K status.
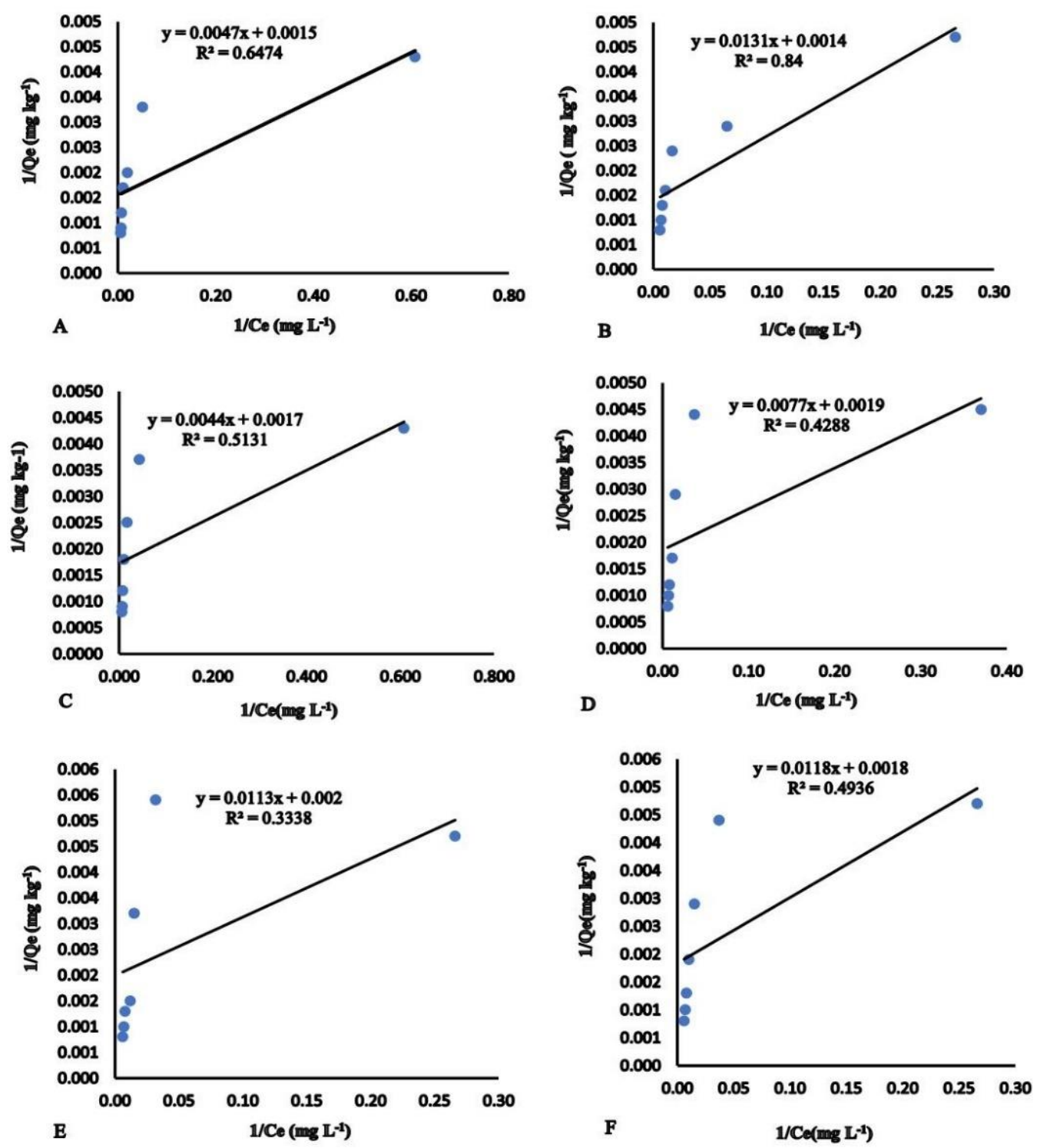

Figure 5: Langmuir adsorption isotherm for (A) Bestan Sur, (B) Serwan, (C) Grdigo, (D) Khurmal. (E) Kharpany, and (F) Kanypanka locations.

The Temkin isotherm equilibrium parameters are calculated from the intercept and slope of the straight-line equation of figure 6 . The binding constant, $A_{T}\left(\mathrm{~L} \mathrm{~kg}^{-1}\right)$ value, ranged from $(0.003$ 
to 0.479 ) $\mathrm{L} \mathrm{kg}^{-1}$ (Table 2), the soil of Kanypanks location had a high binding constant. The values of $b_{T}$ ranged from 10.46 to $13.47 \mathrm{~J} \mathrm{~mole}^{-1}$ with the mean of $11.86 \mathrm{~J} \mathrm{~mole}^{-1}$, A positive value of $b t$ implies that the adsorption processes in the soil of the analyzed areas are exothermic. Furthermore, high constant values related to sorption heat, $\mathrm{B}\left(\mathrm{J} \mathrm{mol}^{-1}\right)$ demonstrate a high contact between the adsorbent and that of adsorbate, implying the mechanism of the exchange of ion [26]. These findings are consistent with the results of Mam Rasul [41].
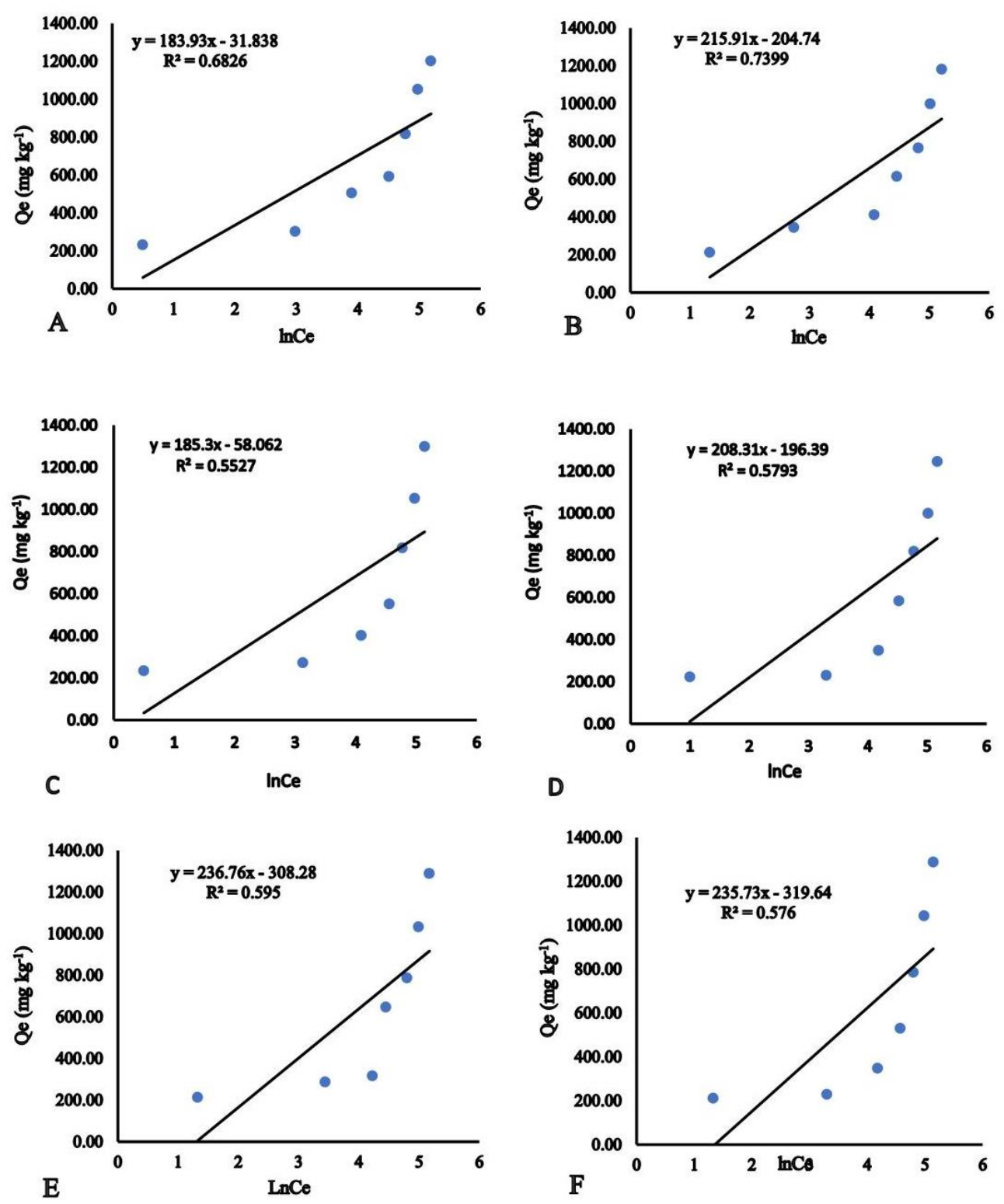

Figure 6: Temkin adsorption isotherm for (A) Bestan Sur, (B) Serwan, (C) Grdigo, (D) Khurmal. (E) Kharpany, and (F) Kanypanka locations. 


\section{CONCLUSION AND RECOMMENDATION}

The importance of isotherms in assessing soil $\mathrm{K}$ adsorption characteristics was revealed by the outcomes of this study. The low $1 / \mathrm{n}$ values of the soils investigated suggest that the soil has a low buffering capacity. Exchangeable potassium has high binding energy on exchangeable sites. These showed that the crop in the examined soils had a limited supply of K. As a result, it can be observed that $\mathrm{K}$ fertilizer is required to restore the soil solution $\mathrm{K}$ in the examined soils. This suggested that crops in the examined soils were inadequate in $\mathrm{K}$, proposing that $\mathrm{K}$ should be one of the soil management options.

\section{REFERENCES}

[1] P. White, A. Karley, R. Potassium, and R. Mendel, "Cell biology of metals and nutrients," Plant Cell Monographs, Springer, Berlin, pp. 199-224, 2010.

[2] V. Römheld and G. Neumann, "The rhizosphere: contributions of the soil-root interface to sustainable soil systems," Biological approaches to sustainable soil systems, pp. 92-107, 2006.

[3] H. Zhang, M. Xu, W. Zhang, and X. He, "Factors affecting potassium fixation in seven soils under 15-year long-term fertilization," Chinese Science Bulletin, vol. 54, pp. 1773-1780, 2009.

[4] M. Simonsson, S. Andersson, Y. Andrist-Rangel, S. Hillier, L. Mattsson, and I. Öborn, "Potassium release and fixation as a function of fertilizer application rate and soil parent material," Geoderma, vol. 140, pp. $188-198,2007$.

[5] G. Rehm and M. Schmitt, "Potassium for crop production," Retrieved February, vol. 2, p. 2011, 2002.

[6] a. D. S. S. Shanwall A. V.,. "Potassium Dynamics and Mineralogy," Taylor and Francis, Encyclopedia of Soil Science, vol. 2, p. 4, 2006.

[7] Y. Du, S. Hayashi, and Y. Xu, "Some factors controlling the adsorption of potassium ions on clayey soils," Applied Clay Science, vol. 27, pp. 209-213, 2004.

[8] M. Jalali, "Kinetics of non-exchangeable potassium release and availability in some calcareous soils of western Iran," Geoderma, vol. 135, pp. 63-71, 2006.

[9] M. Simonsson, S. Hillier, and I. Öborn, "Changes in clay minerals and potassium fixation capacity as a result of release and fixation of potassium in long-term field experiments," Geoderma, vol. 151, pp. 109-120, 2009.

[10] M. Murashkina, R. Southard, and G. Pettygrove, "Potassium fixation in San Joaquin Valley soils derived from granitic and nongranitic alluvium," Soil Science Society of America Journal, vol. 71, pp. 125-132, 2007.

[11] R. Pannu, Y. Singh, B. Singh, and C. Khind, "Long term effects of organic materials on depth wise distribution of different $\mathrm{K}$ fractions in soil profile under rice-wheat cropping system," Journal of Potassium Research, vol. 18, pp. 1-5, 2002.

[12] N. Barrow, "The description of phosphate adsorption curves," Journal of Soil Science, vol. 29, pp. 447-462, 1978.

[13] J. F. Porter, G. McKay, and K. Choy, "The prediction of sorption from a binary mixture of acidic dyes using single-and mixed-isotherm variants of the ideal adsorbed solute theory," Chemical Engineering Science, vol. 54, pp. 5863-5885, 1999.

[14] N. Atar, A. Olgun, and S. Wang, "Adsorption of cadmium (II) and zinc (II) on boron enrichment process waste in aqueous solutions: batch and fixed-bed system studies," Chemical Engineering Journal, vol. 192, pp. 1-7, 2012.

[15] G. W. Gee and D. Or, "2.4 Particle-size analysis," Methods of soil analysis: Part 4 physical methods, vol. 5, pp. 255-293, 2002.

[16] D. L. Suarez, "Beryllium, magnesium, calcium, strontium, and barium," Methods of Soil Analysis: Part 3 Chemical Methods, vol. 5, pp. 575-601, 1996.

[17] D. W. Nelson and L. E. Sommers, "Total carbon, organic carbon, and organic matter," Methods of Soil Analysis: Part 3 Chemical Methods, vol. 5, pp. 961-1010, 1996.

[18] G. Rayment and F. R. Higginson, Australian laboratory handbook of soil and water chemical methods: Inkata Press Pty Ltd, 1992.

[19] G. Drouineau, "Dosage rapide du calcaire actif du sol: Nouvelles données sur la separation et la nature des fractions calcaires," Ann. Agron, vol. 12, pp. 441-450, 1942.

[20] S. Mandal, T. Padhi, and R. Patel, "Studies on the removal of arsenic (III) from water by a novel hybrid material," Journal of hazardous materials, vol. 192, pp. 899-908, 2011.

[21] B. M. Vanderborght and R. E. Van Grieken, "Enrichment of trace metals in water by adsorption on activated carbon," Analytical Chemistry, vol. 49, pp. 311-316, 1977.

[22] K. Y. Foo and B. H. Hameed, "Insights into the modeling of adsorption isotherm systems," Chemical Engineering Journal, vol. 156, pp. 2-10, 2010.

[23] A. W. Adamson and A. P. Gast, Physical chemistry of surfaces vol. 15: Interscience publishers New York, 1967. 
[24] E. Voudrias, K. Fytianos, and E. Bozani, "Sorption-desorption isotherms of dyes from aqueous solutions and wastewaters with different sorbent materials," Global Nest Int. J, vol. 4, pp. 75-83, 2002.

[25] S. Puttamat and V. Pavarajarn, "Adsorption study for removal of Mn (II) ion in aqueous solution by hydrated ferric (III) oxides," International Journal of Chemical Engineering and Applications, vol. 7, pp. 239-243, 2016.

[26] A. Dada, A. Olalekan, A. Olatunya, and O. Dada, "Langmuir, Freundlich, Temkin and DubininRadushkevich isotherms studies of equilibrium sorption of $\mathrm{Zn} 2+$ unto phosphoric acid modified rice husk," IOSR Journal of Applied Chemistry, vol. 3, pp. 38-45, 2012.

[27] F. Rashidi, R. S. Sarabi, Z. Ghasemi, and A. Seif, "Kinetic, equilibrium and thermodynamic studies for the removal of lead (II) and copper (II) ions from aqueous solutions by nanocrystalline TiO2," Superlattices and microstructures, vol. 48, pp. 577-591, 2010.

[28] G. T. Rushton, C. L. Karns, and K. D. Shimizu, "A critical examination of the use of the Freundlich isotherm in characterizing molecularly imprinted polymers (MIPs)," Analytica chimica acta, vol. 528, pp. 107-113, 2005.

[29] C. Namasivayam and R. Yamuna, "Waste biogas residual slurry as an adsorbent for the removal of Pb (II) from aqueous solution and radiator manufacturing industry wastewater," Bioresource Technology, vol. 52, pp. 125-131, 1995

[30] K. V. Kumar and S. Sivanesan, "Isotherm parameters for basic dyes onto activated carbon: Comparison of linear and non-linear method," Journal of hazardous materials, vol. 129, pp. 147-150, 2006.

[31] G. Mckay, H. Blair, and J. Gardner, "The adsorption of dyes onto chitin in fixed bed columns and batch adsorbers," Journal of Applied Polymer Science, vol. 29, pp. 1499-1514, 1984.

[32] S. Khattri and M. Singh, "Adsorption of basic dyes from aqueous solution by natural adsorbent," 1999.

[33] A. Reyhanitabar, N. Karimian, M. Ardalan, G. Savaghebi, and M. Ghannadha, "Comparison of five adsorption isotherms for prediction of zinc retention in calcareous soils and the relationship of their coefficients with soil characteristics," Communications in soil science and plant analysis, vol. 38, pp. 147$158,2007$.

[34] G. O. Wood, "Affinity coefficients of the Polanyi/Dubinin adsorption isotherm equations: A review with compilations and correlations," Carbon, vol. 39, pp. 343-356, 2001.

[35] K. Vijayaraghavan, T. Padmesh, K. Palanivelu, and M. Velan, "Biosorption of nickel (II) ions onto Sargassum wightii: application of two-parameter and three-parameter isotherm models," Journal of hazardous materials, vol. 133, pp. 304-308, 2006.

[36] N. A. Fathy, O. I. El-Shafey, and L. B. Khalil, "Effectiveness of alkali-acid treatment in enhancement the adsorption capacity for rice straw: the removal of methylene blue dye," International Scholarly Research Notices, vol. 2013, 2013.

[37] K. D. Auge, T. M. Assefa, W. H. Woldeyohannes, and B. T. Asfaw, "Potassium adsorption characteristics of five different textured soils under enset (Ensete ventricosom cheesman) farming systems of Sidama zone, South Ethiopia," Journal of Soil Science and Environmental Management, vol. 9, pp. 1-12, 2018.

[38] M. Kassa, W. Haile, and F. Kebede, "Evaluation of adsorption isotherm models for potassium adsorption under different soil types in Wolaita of Southern Ethiopia," Communications in soil science and plant analysis, vol. 50, pp. 388-401, 2019.

[39] S. Mandzhieva, T. Minkina, D. Pinskiy, T. Bauer, and S. Sushkova, "The role of soil's particle-size fractions in the adsorption of heavy metals," Eurasian Journal of Soil Science, vol. 3, pp. 197-205, 2014.

[40] O. Kenyanya, J. M. Wachira, and H. Mbuvi, "Determination of potassium levels in intensive subsistence agricultural soils in Nyamira County, Kenya," 2013.

[41] G. A. Mam Rasul, "Potassium adsorption in calcareous soils of Kurdistan region of Iraq," Iraqi Journal of Agricultural Sciences, vol. 51, 2020.

[42] A. A. Mehadi and R. W. Taylor, "Phosphate adsorption by two highly-weathered soils," Soil Science Society of America Journal, vol. 52, pp. 627-632, 1988.

[43] M. Del Bubba, C. Arias, and H. Brix, "Phosphorus adsorption maximum of sands for use as media in subsurface flow constructed reed beds as measured by the Langmuir isotherm," Water Research, vol. 37, pp. 3390-3400, 2003.

[44] R. Anderson and $\mathrm{Y}$. Wu, "Phosphorus quantity-intensity relationships and agronomic measures of $\mathrm{P}$ in surface layers of soil from a long-term slurry experiment," Chemosphere, vol. 42, pp. 161-170, 2001.

[45] O. Rehman, A. Ranjha, S. Saleem, and A. Khan, "Phosphorus requirement of wheat using modified Freundlich model in Sultanpur (Pakistan) soil series," Int. J. Agric. Biol, vol. 7, pp. 74-78, 2005.

[46] M. Fried and R. Shapiro, "Phosphate supply pattern of various soils," Soil Science Society of America Journal, vol. 20, pp. 471-475, 1956. 